\title{
Impact of coronavirus disease on acute appendicitis cases
}

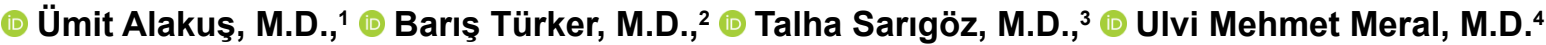 \\ 1'Department of General Surgery, Health Sciences University Gülhane Training and Research Hospital, Ankara-Turkey \\ ${ }^{2}$ Department of General Surgery, Batman State Hospital, Batman-Turkey \\ ${ }^{3}$ Department of General Surgery, Kayseri City Hospital, Department of General Surgery, Kayseri-Turkey \\ ${ }^{4}$ Department of General Surgery, İzmir Katip Çelebi University Atatürk Training and Research Hospital, İzmir-Turkey
}

\begin{abstract}
BACKGROUND: Disease profiles have changed in the COVID-I 9 pandemic. In this study, we aimed to compare acute appendicitis cases before and during the COVID-19 pandemic.

METHODS: A total of 130 patients were diagnosed with AA and operated between the days of first COVID-I9 case on March II, 2020, and May II, 2020, and the same period of the previous year. Data of the patients were extracted from electronic archive of the hospital. Those patients were stratified into two groups; pandemic group and pre-pandemic group. The pandemic group comprised 46 patients and the pre-pandemic group, 84 patients. The two groups were compared in terms of age, gender, duration of symptoms, length of hospital stay, white blood cell count, C-reactive protein levels, and post-operative complications.
\end{abstract}

RESULTS: The median days passed from onset of abdominal pain to submission were 6.5 days in the pandemic period. However, it was 3 days in the pre-pandemic group $(p<0.001)$. Other parameters were not statistically different between the groups $(p>0.05)$.

CONCLUSION: During the COVID-19 pandemic period, delay in hospital submissions has attracted attention. However, delayed treatment did not reflect to the clinic as more severe disease.

Keywords: Appendicitis; complication; coronavirus; delay; submission; surgery.

\section{INTRODUCTION}

The coronavirus disease (COVID-19) pandemic from coronavirus SARS-CoV-2 has seriously affected health systems globally. ${ }^{[1]}$ While researchers have been trying to establish the standards of COVID-19 treatment during the rapidly escalating pandemic, other health services have continued giving healthcare. ${ }^{[2,3]}$ However, there had been concerns raised by surgeons about how clinical follow-up will be affected by this pandemic. ${ }^{[4-6]}$ While elective surgeries were postponed, different approaches have been made since there is no such chance for urgent surgical pathologies. ${ }^{[7]}$ However, there are insufficient data about the impact of the pandemic on the management of these patients.

The COVID-19 pandemic in the Republic of Turkey, which has started relatively late, is part of ongoing pandemic of coronavirus disease. The first cases of COVID-19 were identified in the Republic of Turkey on March I I, 2020, and according to the records of the World Health Organization, it has started being seen as one of the countries with the pandemic as of March 12, 2020. ${ }^{[8]}$ As in all admissions to the hospital, there have been decreases in emergency room visits. Although this situation can be evaluated as a partial reduction in unnecessary emergency department admissions, it was thought that individuals may be afraid to apply to hospitals and, therefore, there may be delays in real emergency situations. This situation caused justified concerns about the risk of disease becoming more complicated during the application. ${ }^{[9]}$

Therefore, in our study, we aimed to examine the effect of the pandemic on the diagnosis and treatment processes of

Cite this article as: Alakuş Ü, Türker B, Sarıgöz T, Meral UM. Impact of coronavirus disease on acute appendicitis cases. Ulus Travma Acil Cerrahi Derg 2022;28:285-289.

Address for correspondence: Talha Sarıgöz, M.D.

Kayseri Şehir Hastanesi, Genel Cerrahi Kliniği, Kayseri, Turkey

Tel: +90352 - 3157700 E-mail: sarigozt.md@gmail.com

Ulus Travma Acil Cerrahi Derg 2022;28(3):285-289 DOI: 10.14744/tjtes.2020.38632 Submitted: 29.07.2020 Accepted: 04.12.2020

Copyright 2022 Turkish Association of Trauma and Emergency Surgery 
acute appendicitis (AA), which is the most common emergency surgical pathology. ${ }^{[10]}$ Furthermore, to see effect of the pandemic on submissions with $A A$, we obtained records from the same period of the previous year and compared them to the pandemic period data.

\section{MATERIALS AND METHODS}

This retrospective study was conducted at Gulhane Military State Hospital state hospital after obtaining approval from the Ministry of Health of Turkey (Date/Number) and Institutional Review Board (2020/Number).

Institutional database was searched for patients underwent surgery for AA and they were stratified into two groups: Pre-pandemic group and pandemic group. A total of 93 patients submitted to the emergency department with abdominal complaints during 2 months period between the days of first COVID-19 case on March II, 2020, and May II, 2020. From those 46 patients who were diagnosed with AA and underwent surgical intervention were enrolled in the pandemic group. In the same period of the previous year (March II, 2019-May II, 2019), a total of I24 patients submitted with abdominal complaints and 84 of them underwent surgery for AA. Those formed the pre-pandemic group (Fig. I).

Demographic and clinical data along with the laboratory parameters of the study subjects were retracted from institutional database for comparison. From data, age, gender, status of appendicocecal disease (with abscess, perforated, accompanying necrosis, plastron, or uncomplicated), white blood cell (WBC) count, C-reactive protein (CRP) levels, and length of hospital stay were used in the statistical analysis. For the evaluation of post-operative complications, Clavien-Dindo classification was used. ${ }^{\left[{ }^{1}\right]}$

Statistical analysis was performed on SPSS 23.0 software package (SPSS, Inc., Chicago, IL). Categorical data were expressed as number (percentage) and continuous data as median (interquartile range $25^{\text {th }}-75^{\text {th }}$ percentile) or mean \pm standard deviation. For statistical comparison between the groups, Chi-square test for categorical data and Student's

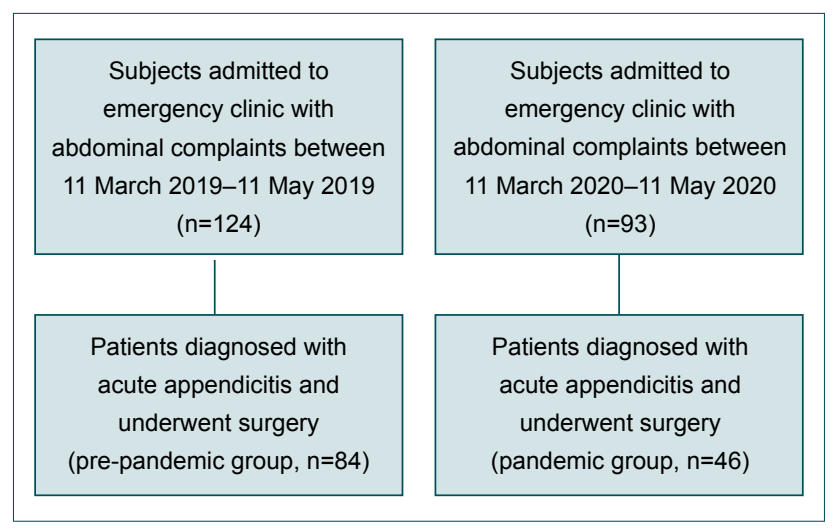

Figure 1. Flow diagram showing patient selection. t-test or Mann-Whitney U-test for continuous data were used. Statistical significance was accepted at 0.05 .

\section{RESULTS}

A total of 130 patients were enrolled in the study. Eightyfour of them were in the pre-pandemic group and 46 were in the pandemic group. When the number of submissions in the pandemic period was compared to the same period of the previous year, significant decrease in patient numbers was observed. The median age of the patients was 29 and majority of them were male. All of the subjects had abdominal pain complaints and duration between onset of abdominal pain and hospital submission in the pandemic group was significantly longer than the pre-pandemic group $(p<0.00 \mathrm{I})$. The median duration was 3 days in the pre-pandemic group and it was 6.5 days in the pandemic group (Table I).

In the pre-pandemic group, the mean WBC count was $14.2 \pm 4.4$ cell $* 10^{3} / \mathrm{mL}$ and it was $14.2 \pm 3.3$ cell $* 10^{3} / \mathrm{mL}$ in the pandemic group. The median value of CRP in the pre-pandemic was 7 and it was 16 in the pandemic group. WBC counts and CRP values of the patients did not differ between the groups. When the pre-pandemic group was evaluated according to surgical intervention results, $4.8 \%$ (4) of patients presented with pericecal abscess and 3.6\% (3) of patients with appendix perforation. However, in the pandemic group, $8.7 \%$ (4) of patients had pericecal abscess, 6.5\% (3) appendix perforation, and $2.2 \%$ (I) appendix necrosis. However, there was no significant difference between the groups regarding accompanying complications $(p=0.189)$. Groups were also evaluated in terms of post-operative complications using Clavien-Dindo classification and there was no significant difference $(p=0.530)$. Only a patient from the pandemic group was rehospitalized a week later due to ileus and treated conservatively. Both groups of patients stayed at the hospital at a median of I day $(p=0.764)$.

\section{DISCUSSION}

In this retrospective study, we evaluated the effects of COVID-19 pandemic on a prevalent emergency disease, AA, and concluded that COVID-19 pandemic may have caused delay in submissions but severity of disease did not increase as expected compared to the same period of the previous year. We believe that fear of COVID-19 spread was the driving factor for delay in the emergency department submissions. However, symptoms of $A A$, such as abdominal pain, may have caused decrease in quality of life and the patients have had to submit to the emergency department even if they are at the late stage of the disease. Despite the conclusion of the $\mathrm{Li}$ et al.' $\mathrm{S}^{[12]}$ review which indicated that total delay is strongly associated with complicated appendicitis, delay by patients will not make them prone to increased morbidity in the pandemic period which is also consistent with the recent body of literature. 
Table I. Characteristics of the patients

\begin{tabular}{|c|c|c|c|}
\hline & Pre-pandemic group $(n=84)$ & Pandemic group $(n=46)$ & p-value \\
\hline Age (years) & $29(2 I-4 I)$ & $29(21-34)$ & 0.501 \\
\hline \multicolumn{4}{|l|}{ Gender, n (\%) } \\
\hline Male & $52(61.9)$ & $32(69.5)$ & \\
\hline Female & $32(38.1)$ & $14(30.5)$ & 0.285 \\
\hline Duration between onset of abdominal pain and submission, $d$ & $3(1-4)$ & $6.5(2-11)$ & $<.001$ \\
\hline White blood cell, cell*103/mL & $14.2 \pm 4.4$ & $14.2 \pm 3.3$ & $>.05$ \\
\hline C-reactive protein, $\mathrm{mg} / \mathrm{dL}$ & $7(2-35)$ & $16(2-74)$ & 0.061 \\
\hline \multicolumn{4}{|l|}{ Accompanying complications, n (\%) } \\
\hline None & 77 (9l.7) & $38(82.6)$ & 0.189 \\
\hline Abscess & $4(4.8)$ & $4(8.7)$ & \\
\hline Perforation & $3(3.6)$ & $3(6.5)$ & \\
\hline Necrosis & $0(0)$ & I (2.2) & \\
\hline Plastron & $0(0)$ & $0(0)$ & \\
\hline \multicolumn{4}{|l|}{ Clavien-Dindo classification } \\
\hline Grade I & 84 & 43 & 0.530 \\
\hline Grade 2 & 0 & 1 & \\
\hline Length of hospital stay (days) & $I(I-2)$ & I (I-2) & 0.764 \\
\hline
\end{tabular}

In a similar study, Romero et al. ${ }^{[13]}$ compared pandemic period with the previous year using radiology department records. They found that the number of computed tomography scans performed for AA suspicion decreased from 42 to 25 in the pandemic period. In another multicenter cohort published by Tankel et al.," ${ }^{[14]}$ it was reported that the number of submissions for AA during the pandemic period decreased from 237 to $14 \mid$. They indicated that this decrease could be seasonal or patients were not referred to the emergency department. Likewise, they argued that it may be due to a decrease in incidence of $A A$ in the recent years. In our study, a total of 130 patients underwent appendectomy for AA. While the number of patients with AA during the pandemic period was 46 (35.3\%), there were $84(64.6 \%)$ patients in the same period of 2019. Similar to the literature, there was marked decrease in AA cases. Since our control group was the same period of the previous year, it is clear that this decrease in submissions is not seasonal.

In their study, Romero et al. ${ }^{[13]}$ also staged AA according to the tomography findings and reported that patients diagnosed with appendicitis during the pandemic period had a more advanced radiological stage. They attributed this statistically significant difference to patients' late submission. In their multicenter study, Tankel et al. ${ }^{[14]}$ reported that they did not find a statistically significant difference between the onset of complaints and the hospital admission, neutrophil count, and rate of complications in patients treated for appendicitis. In our study, we evaluated CRP levels of both groups to have an idea about the severity of disease but statistically signifi- cant difference was not observed between them although the time passed from onset of pain to admission to hospital were longer in the pandemic group $(p=0.06 \mathrm{I})$.

Non-operative treatment of uncomplicated appendicitis cases has been popular recently. ${ }^{[15]}$ In a survey study of Kelly et al. ${ }^{[7]}$ with the participation of 161 surgeons, they found that $71 \%$ of surgeons preferred conservative treatment for patients diagnosed with AA during the pandemic period. In addition, $84 \%$ of the surgeons indicated that they would return to surgical intervention after the pandemic. On the contrary to $71 \%$ of the surgeons, in our study, all patients diagnosed with appendicitis received surgical treatment independently from time period. In our hospital, we observed that surgeons still prioritize the surgical intervention and did not consider conservative treatment during the pandemic period. Relatively low number of complications can be attributed to the surgeon preference. We should also state that there was not mortality from COVID- 19 following surgical intervention.

In their study examining 378 patients with AA, Tankel et al. ${ }^{[14]}$ reported that they found pre-pandemic and pandemic period length of hospital stay as 2.5 days and 2.3 days, respectively. During the pandemic period, they did not find any increase in hospital stay. In our study, we also did not find any difference in length of hospital stay between the groups. In this regard, we believe that the pandemic period had no significant effect on the clinic. Similarly, there was no difference between the groups in terms of post-operative complications. 
There are limitations to this study that should be addressed. The number of cases was low due to the short duration and being single centered. In addition, due to the rapid escalation of the pandemic, the study was conducted in a retrospective manner using patient records.

In the COVID-19 pandemic period, the most common surgical pathology requiring surgical intervention was AA. However, a decrease was seen in the number of AA cases during the pandemic. In addition, days passed between the onset of abdominal pain and hospital submission increased. Moreover, patients with AA were found to have relatively higher CRP levels at initial submission compared to subjects operated in the same period of the previous year. However, there was not statistically significant difference between the both groups in terms of length of hospital stay and complication rates.

\section{Conclusion}

In this group of patients, the COVID-19 pandemic did not have significant effect on the prognosis of AA. The delay in submission to hospital did not reflect to the clinic as more severe disease.

Ethics Committee Approval: This study was approved by the Batman Region State Hospital Ethics Committee (Date: 08.06.2020, Decision No: 239).

Peer-review: Internally peer-reviewed.

Authorship Contributions: Concept: B.T., T.S.; Design: B.T., T.S.; Supervision: B.T., T.S.; Resource: Ü.A., U.M.M.; Data: Ü.A., U.M.M.; Analysis: Ü.A.; Literature search: Ü.A.; Writing: Ü.A., B.T., T.S.; Critical revision: B.T., T.S., U.M.M.

Conflict of Interest: None declared.

Financial Disclosure: The authors declared that this study has received no financial support.

\section{REFERENCES}

1. Wu Y, Ho W, Huang Y, Jin DY, Li S, Liu SL, et al. SARS-CoV-2 is an appropriate name for the new coronavirus. Lancet 2020;395:949-50.
2. Soreide K, Hallet J, Matthews JB, Schnitzbauer AA, Line PD, Lai PB, et al. Immediate and long-term impact of the COVID-19 pandemic on delivery of surgical services. Br J Surg 2020;107:1250-61. [CrossRef]

3. De Simone B, Chouillard E, Di Saverio S, Pagani L, Sartelli M, Biffl WL, et al. Emergency surgery during the COVID-19 pandemic: What you need to know for practice. Ann R Coll Surg Engl 2020;102:323-32. [CrossRef]

4. Scott C, Lambert A. Managing appendicitis during the COVID-19 pandemic in the UK. Br J Surg 2020;107:e271. [CrossRef]

5. Guerci C, Maffioli A, Bondurri AA, Ferrario L, Lazzarin F, Danelli P. COVID-19: How can a department of general surgery survive in a pandemic? Surgery 2020;167:909-11. [CrossRef]

6. Pilato E, Manzo R, Comentale G. COVID-19 and ischemic heart disease emergencies: What cardiac surgery should expect? J Card Surg 2020;35:1161. [CrossRef]

7. Kelly ME, Murphy E, Bolger JC, Cahill RA. COVID-19 and the treatment of acute appendicitis in Ireland: A new era or short-term pivot? Colorectal Dis 2020;22:648-9. [CrossRef]

8. Coronavirus Disease 2019 (COVID-19) Situation Report No. 52; 2019. Available from: https://www.who.int/docs/default-source/coronaviruse/ situation-reports/20200312-sitrep-52-covid-19.pdf?sfvrsn=e2bfc9c0_4

9. Patriti A, Eugeni E, Guerra F. What happened to surgical emergencies in the era of COVID-19 outbreak? Considerations of surgeons working in an Italian COVID-19 red zone. Updates Surg 2020;72:309-10. [CrossRef]

10. Williams GR. Presidential address: A history of appendicitis. With anecdotes illustrating its importance. Ann Surg 1983;197:495-506. [CrossRef]

11. Dindo D, Demartines N, Clavien PA. Classification of surgical complications: A new proposal with evaluation in a cohort of 6336 patients and results of a survey. Ann Surg 2004;240:205-13. [CrossRef]

12. Li J, Xu R, Hu DM, Zhang Y, Gong TP, Wu XL. Effect of delay to operation on outcomes in patients with acute appendicitis: A systematic review and meta-analysis. J Gastrointest Surg 2019;23:210-23. [CrossRef]

13. Romero J, Valencia S, Guerrero A. Acute appendicitis during Coronavirus disease 2019 (COVID-19): Changes in clinical presentation and CT findings. J Am Coll Radiol 2020;17(8):1011-3. [CrossRef]

14. Tankel J, Keinan A, Blich O, Koussa M, Helou B, Shay S, et al. The decreasing incidence of acute appendicitis during COVID-19: A retrospective multi-centre study. World J Surg 2020;44:2458-63. [CrossRef]

15. Collard M, Lakkis Z, Loriau J, Mege D, Sabbagh C, Lefevre JH, et al. Antibiotics alone as an alternative to appendectomy for uncomplicated acute appendicitis in adults: Changes in treatment modalities related to the COVID-19 health crisis. J Visc Surg 2020;157:S33-42. [CrossRef] 


\section{ORİJINAL ÇALIŞMA - ÖZ}

\section{Koronavirüs hastalığının akut apandisit olguları üzerindeki etkisi}

\section{Dr. Ümit Alakuş, ${ }^{1}$ Dr. Barış Türker, ${ }^{2}$ Dr. Talha Sarıgöz, ${ }^{3}$ Dr. Ulvi Mehmet Meral ${ }^{4}$}

${ }^{1}$ Sağlık Bilimleri Üniversitesi Gülhane Eğitim ve Araştırma Hastanesi, Genel Cerrahi Anabilim Dalı, Ankara ${ }^{2}$ Batman Bölge Devlet Hastanesi, Genel Cerrahi Kliniği, Batman

${ }^{3}$ Kayseri Şehir Hastanesi, Genel Cerrahi Kliniği, Kayseri

${ }^{4}$ İzmir Katip Çelebi Üniversitesi Atatürk Eğitim ve Araştırma Hastanesi, Genel Cerrahi Kliniği, İzmir

AMAÇ: Hastalık profilleri Covid-19 pandemi sürecinde değişiklik göstermiştir. Bu çalışmada Covid- 19 pandemi öncesi ve pandemi süresince akut apandisit olgularını karşılaştırmayı amaçladık.

GEREÇ VE YÖNTEM: Illk Covid-1 9 olgusunun görüldüğü II Mart 2020 ve I I Mayıs 2020 arasında ve geçen yılın aynı döneminde toplamda I30 hasta akut apandisit tanısı ile ameliyat oldu. Hastaların verileri hastanenin elektronik arşivinden elde edildi. Bu hastalar iki gruba ayrıldı; pandemik grubu ve pandemik öncesi grup. Pandemi grubunda 46 hasta, pandemik öncesi grupta 84 hasta yer aldı. íki grup yaş, cinsiyet, şikayetlerin süresi, hastanede kalış süresi, beyaz küre sayımı, C-reaktif protein düzeyi ve ameliyat sonrası komplikasyonlar açısından karşılaştırıldı.

BULGULAR: Karın ağıısının başlangıcı ve başvuru arasında geçen ortanca gün pandemi grubunda 6.5 gündü. Oysa ki bu süre pandemik öncesi grupta üç gündü $(p<0.00 I)$. Diğer parametreler gruplar arasında istatistiksel olarak farklı değildi $(p>0.05)$.

TARTIŞMA: Covid- 19 pandemi periyodu süresince hastaneye başvurularda gecikme dikkat çekmiştir. Ancak gecikmiş tedavi kliniğe daha ciddi hastalık olarak yansımamıştır.

Anahtar sözcükler: Apandisit; başvuru; cerrahi; coronavirus; gecikme; komplikasyon.

Ulus Travma Acil Cerrahi Derg 2022;28(3):285-289 doi: 10.14744/tjtes.2020.38632 